\title{
Gender Trouble and Cross-Dressing in Early Modern England
}

\author{
David Cressy
}

A celebrated article in Shakespeare Quarterly opens with the question, 'how many people cross-dressed in Renaissance England?' Jean Howard, who posed this intriguing question, suggests that disruption of the semiotics of dress, gender, and identity during the late Elizabethan and Jacobean periods points to "a sex-gender system under pressure" and a patriarchal culture disturbed by profound anxieties and contradictions. Even if the answer to her question turns out to be "very few," the discourse surrounding the practice reveals an area of critical and problematic unease. Female transvestism on the streets of London, male transvestism on the stage, and vituperative attacks on cross-dressing by Protestant reformers are among the symptoms that indicate that "the subversive or transgressive potential of this practice could be and was recuperated in a number of ways." Dressing boy actors for female roles, for example, was not simply "an unremarkable convention within Renaissance dramatic practice," as some scholars have suggested, but rather a scandalous "source of homoerotic attraction" arousing "deep-seated fears" of an "unstable and monstrous" and feminized self.' Whether in real life or in literature, by this account, cross-dressing involved struggle, resistance, and subversion, as well as modification, recuperation, and

DAvid CRESSY is professor of history at California State University, Long Beach. Earlier versions of this article were presented at the Huntington Library, in San Marino, Calif., May 1994, at the North American Conference on British Studies at Vancouver in October 1994, and at a conference on "Virtual Gender: Past Projections, Future Histories," at Texas A\&M University, College Station, in April 1996. He would like to thank all those who helped with criticisms and suggestions.

1 Jean E. Howard, "Crossdressing, the Theatre, and Gender Struggle in Early Modern England," Shakespeare Quarterly 39 (1988): 418-40, quotes on 418, 419 and n. 3. Howard's article has been reprinted in Lesley Ferris, ed., Crossing the Stage: Controversies on Cross-Dressing (London and New York, 1993), pp. 20-46. A modified and evolved discussion, reiterating the original question, appears in Jean Howard, The Stage and Social Struggle in Early Modern England (London, 1994), esp. pp. 94-104.

Journal of British Studies 35 (October 1996): 438-465

(C) 1996 by the North American Conference on British Studies.

All rights reserved. 0021-9371/96/3504-0002\$01.00 
containment of the system of gendered patriarchal domination. Renaissance cross-dressing involved ideological work of a complex kind that ultimately, in Howard's materialist feminist analysis, "participated in the historical process eventuating in the English Revolution." 2 This is a claim that may make English historians gasp, but it is one that they cannot ignore.

This article sets out to consider the ramifications of Howard's provocative question and the range of possible responses. Writing as a historian in an area dominated by literary scholars, I intend to reframe the discussion in cultural, historical, and perhaps even disciplinary terms, while offering my own reading of selected early modern plays. I shall also introduce some archival evidence that invites us to reexamine the social and sexual confusions of transvestism and to question certain judgments about the culture of early modern England. Cross-dressing, I argue, was not so transgressive as critics and scholars have suggested, nor was it necessarily symptomatic of a sex-gender system in distress. Much of my emphasis will be on cross-dressed men, partly because they have received less attention than women, but also because the cross-disciplinary reading of this material seems most disjunctive.

Literary Renaissance scholars are fascinated by cross-dressing, by men wearing women's costumes or women dressed like men. Whether they focus on boy actors taking female roles, female characters donning male attire, male characters wearing drag, or London prostitutes sporting mannish attire, literary scholars often argue that cross-gender clothing signaled subversion, resistance, and transgression and that the sex-gender system of early modern England was in a state of flux. Cross-dressing, we are told, upset patriarchal values, assaulted cultural boundaries, and unraveled the sexual separators of ambivalence, androgyny, and eroticism. Historians, by contrast, have shown little interest in these issues. ${ }^{3}$

${ }^{2}$ Howard, "Crossdressing," pp. 419, 436, quote on p. 436.

${ }^{3}$ Linda Woodbridge, Women and the English Renaissance: Literature and the Nature of Womankind, 1540-1620 (Urbana, Ill., and Chicago, 1984), pp. 139-58; Laura Levine, Men in Women's Clothing: Anti-theatricality and Effeminization, 1579-1642 (Cambridge and New York, 1994), pp. 1-25; Lisa Jardine, "Boy Actors, Female Roles, and Elizabethan Eroticism," in Staging the Renaissance: Reinterpretations of Elizabethan and Jacobean Drama, ed. David Scott Kastan and Peter Stallybrass (New York and London, 1991), pp. 57-67, and Still Harping on Daughters: Women and Drama in the Age of Shakespeare (Totawa, N.J., 1983), pp. 9-36; Phyllis Rackin, "Androgyny, Mimesis, and the Marriage of the Boy Heroine on the English Renaissance Stage," PMLA 102 (1987): 29-41; Stephen Greenblatt, Shakespearian Negotiations: The Circulation of Social Energy in Renaissance England (Berkeley, 1988); Mary Beth Rose, The Expense of Spirit: Love and Sexuality in English Renaissance Drama (Ithaca, N.Y., 1988); Stephen Orgel, "Nobody's Perfect: or, Why Did the English Stage Take Boys for Women?' South Atlantic Quarterly 88 (1989): 7-29; Katherine E. Kelly, 'The Queen's Two Bodies: Shakespeare's Boy 
Two types of cross-dressing have recently caught the attention of literary scholars. First, the women of Renaissance England who began adopting masculine attire, and second, the boys and young men who took female parts, and dressed in female costume, in the course of dramatic performances on stage. The first is represented as a challenge to patriarchal values, a bold assault on oppressive cultural boundaries; the second as marking the sexual ambivalence, androgyny, and muted eroticism linking actors, dramatists, and playgoers in a sexually charged subculture of transgression. Both phenomena were disturbing to moralists and reformers, and both offer interpretative opportunities to modern cultural critics. Not surprisingly, they open avenues to politicized discourse about sexuality, self-representation, and gender that has become increasingly fashionable in our own contested culture within the last dozen years. ${ }^{4}$

Linda Woodbridge has identified not simply isolated and ambiguous cases of women "masking in men's weeds" but a full-blown "female transvestite movement" in early modern England. Its indications were everywhere, she finds, not just in literary polemic and satire but in "real life" too, becoming "a fairly permanent feature of the Jacobean landscape." ${ }^{5}$ Women dressed as men, Woodbridge suggests, for a variety of admirable reasons: to plead at law, regain a fortune, or practice a profession barred to women; to advance a stratagem, win back lovers, or fight a duel; to travel alone, avoid rape or molestation, and to have adventures. The cross-dressed women, in this rendition, were bold and ingenious, their actions commendably shrewd. The evidence that supports this de-

Actress in Breeches," Theatre Journal 42 (1990): 81-93; Steve Brown, "The Boyhood of Shakespeare's Heroines: Notes on Gender Ambiguity in the Sixteenth Century," Studies in English Literature, 1500-1900, 30 (1990): 243-63; Ursula K. Heise, "Transvestism and the Stage Controversy in Spain and England, 1580-1680," Theatre Journal 44 (1992): 357-74; Susan Zimmerman, ed., Erotic Politics: Desire on the Renaissance Stage (New York and London, 1992). For a somewhat more cautious account, see Michael Shapiro, Gender in Play on the Shakespearean Stage: Boy Heroines and Female Pages (Ann Arbor, Mich., 1994). Among the few historical engagements with this topic, see Athony Fletcher, "Men's Dilemma: The Future of Patriarchy in England, 1560-1660," Transactions of the Royal Historical Society, 6th ser., 4 (1994): 61-81, and Gender, Sex and Subordination in England, 1500-1800 (New Haven, Conn., and London, 1995).

${ }^{4}$ Judith Butler, Gender Trouble: Feminism and the Subversion of Identity (New York and London, 1990); Marjorie Garber,Vested Interests: Cross-Dressing and Cultural Anxiety (New York and London, 1992); Druann Pagliassotti, "On the Discursive Construction of Sex and Gender," Communication Research 20 (1993); 472-93; David Kuchta, "The Semiotics of Masculinity in Renaissance England," in Sexuality and Gender in Early Modern Europe, ed. James Grantham Turner (Cambridge, 1993), pp. 233-45; Mark Breitenberg, "Anxious Masculinity: Sexual Jealousy in Early Modern England,' Feminist Studies 19 (1993): 377-98.

${ }^{5}$ Woodbridge, pp. 141, 224. Rose (p. 69n.) points out that Woodbridge finds "more coherence and range" in this alleged "transvestite movement" than the pamphlet literature can document. 
piction comes mainly from literary sources, especially plays like The Roaring Girl by Thomas Dekker and Thomas Middleton, read against antitheatrical misogynist writings like Phillip Stubbes's Anatomie of Abuses. The degree to which this creative or polemical literature was grounded in social practice is never convincingly shown, although it is somehow held to reflect "real-life fashion" and "contemporary reality too." 6

Several related studies of Elizabethan and Jacobean literature suggest that early modern England was preoccupied with problems of gender and costume and that the theater provided special sites for the exploration of sexual problems. Shakespeare, one scholar tells us, invited his audience "to view themselves as gendered subjects acting out a drama of sexual difference." Shakespeare's world, another tells us, was tormented by "the problematics of the flesh." The theater, says a third, was "a medium for the release of transgressive erotic impulses."' The crossdressed male was a familiar figure in literature and was used, so it has been suggested, to explore themes of "erotic androgyny" and homosexuality that could not be treated more directly. Early modern culture appears to have been obsessed with "images of androgynous breakdown" in which "the hermaphroditic actor becomes the embodiment of all that is frightening about the self." "Cross-dressing," Jonathan Dollimore suggests, "epitomizes the strategy of transgressive reinscription" addressing "intense anxieties" about the "unsettling of gender and class hierarchies." "Cross-dressing," Susan Zimmerman adds, "had a disturbing, anarchic potential."

Many of these threads come together in a recent study by Laura Levine, Men in Womens's Clothing, which endorses the claim that the theater dissolved and effeminized masculinity through changes of dress.

${ }^{6}$ Woodbridge, pp. 150, 153, 156. Woodbridge cites The Mous Trap (1606), The Cuckow (1607), The Fair Maid of Bristow (ca. 1604), The Fleire (ca. 1608), and The Roaring Girl (ca. 1608) among plays in which women adopt masculine attire. See also Marjorie Garber, "'The Logic of the Transvestite: The Roaring Girl (1608),' in Kastan and Stallybrass, eds., pp. 221-34; Stephen Orgel, "The Subtexts of The Roaring Girl," pp. 12-26, and Jean E. Howard, "Sex and Social Conflict: The Erotics of The Roaring Girl," pp. 170-90, both in Zimmerman, ed.

${ }^{7}$ Kelly, p. 92; Brown, p. 249; Susan Zimmerman, "Disruptive Desire: Artifice and Indeterminacy in Jacobean Comedy," in Zimmerman, ed., p. 42.

${ }^{8}$ Winfried Schleiner, "Male Cross-Dressing and Transvestism in Renaissance Romances," Sixteenth Century Journal 19 (1988): 605-19; Laura Levine, "Men in Women's Clothing: Anti-theatricality and Effeminization from 1579 to 1642," Criticism 28 (1986): 136, 130; Jonathan Dollimore, "Shakespeare, Cultural Materialism, Feminism and Marxist Humanism," New Literary History 21 (1990): 483; Zimmerman, p. 43. Note, however, the more circumspect remarks by Stephen Orgel, "The Subtexts of The Roaring Girl," on "the eye of the beholder" and Lisa Jardine on "textual imputation" in Zimmerman, ed., pp. 14, 28. 
Male characters who went as women became reduced, powerless, or degenerate because their masculine identity itself was fluid, pliable, and unstable. "It is as if femaleness were the default position," Levine suggests, "the thing one were always in danger of slipping into." Puritan polemicists, she argues, betrayed their fear that clothing could actually alter gender since cross-dressing supposedly had the "power to alter and unman the male body itself." Early modern culture, she concludes, was animated by anxiety about "castration, porousness, effeminization, otherness" and, above all, by "the terror that there is no masculine self.",

Observations of this sort abound in Renaissance literary studies but are rarely made by historians. Partly, I suspect, this has to do with disciplinary rhetorical conventions. But it also reflects different ways of reading texts, different ways of discussing evidence, and different ways of thinking about gender.

Contemporary moralists knew exactly what was wrong and fumed at unnatural and outlandish violations of costume. If it was unsettling, in an age of ambitious self-fashioning, that people used clothing to misrepresent their social status, ${ }^{10}$ it was downright disturbing if they misrepresented their gender by dress. It was unconscionable that the sign should missignify, the costume deceive. Worst of all was the unnatural impiety involved, in violation of the law of God, since outward apparel intimated inward characteristics and the wearer of cross-sexed clothing trod the slope to monstrous degeneration. Was it not written in Deuteronomy that transvestism was an abomination unto the Lord? ${ }^{11}$ Most of this diatribe was directed against representation and misrepresentation in the theater, but it was generalized in polemical discourse to indict all disorderly costuming, off-stage as well as on. One did not have to be a puritan to ask, with George Gascoigne in 1576, "What be they, women, masking in men's weeds? They be so sure even Wo to Men indeed." 12

Writing in the middle of the Elizabethan era, Stephen Gosson argued that it was an "abomination unto the lord" to counterfeit the opposite

${ }^{9}$ Levine, Men in Women's Clothing (n. 3 above), pp. 1-25, quotes on pp. 5, 8, 9.

${ }^{10}$ Wilfrid Hooper, "The Tudor Sumptuary Laws," English Historical Review 30 (1915): 433-49; Frances Elizabeth Baldwin, Sumptuary Legislation and Personal Regulation in England (Baltimore, 1926). We need a modern historical analysis of the social semiotics of costume.

${ }^{11}$ Deut. 22:5: "The woman shall not wear that which pertaineth unto a man, neither shall a man put on a woman's garment: for all that do so are abomination unto the Lord thy God.'

${ }^{12}$ George Gascoigne, The Steel Glas: A Satyre (1576), quoted in Rose, p. 68. 
sex. "The law of God," he protested, "very straightly forbids men to put on women's garments."' Garments, Gosson explained, "'are set down for signs distinctive between sex and sex; to take unto us those garments that are a manifest sign of another sex is to falsify, forge and adulterate, contrary to the express rule of the word of God." ${ }^{13}$ William Harrison reported meeting "some of these trulls in London so disguised that it hath passed my skill to discern whether they were men or women. Thus it is now come to pass that women are become men and men transformed into monsters." 14

Men who attired themselves in "the habits and ornaments of women," wrote Thomas Beard in his thrice-printed Theatre of God's Ivdgements, became "lascivious and effeminate . . . monstrous . . dishonest and ignominious." 15 Continuing the attack at the end of Elizabeth's reign, John Rainolds found women's clothing "a great provocation" to wantonness and lust. "A woman's garment being put on a man doth vehemently touch and move him with the remembrance and imagination of a woman," stirring up uncontrollable feelings of lechery, a sensation Rainolds may have recalled from acting in woman's clothes as a youth. "'What do they teach or stir up in us but lusts," asked the preacher Adam Hill of stage players, "whose bodies being made weak and wanton in imitating the going and apparel of women, do counterfeit unchaste women with unhonest gestures?' 17 Cross-dressing clearly touched a raw nerve and produced, in these reformers, a recirculating rhetoric of anxiety and fear.

Phillip Stubbes, furious at multiple abuses, likewise fulminated against women who dressed like men and men who dressed like women. Transvestism, Stubbes reiterated, was offensive to God. "It is written in the 22nd. of Deuteronomy," he reminded his readers, "that what man soever weareth woman's apparel is accursed, and what woman weareth man's apparel is accursed also." Male and female costumes were divinely ordained as God-given markers, so their misapplication subverted the fundamental structure of God's universal plan. For a man to wear effeminate costume made him "weak, tender and infirm," indeed, womanish. For a woman to dress like a man undercut the established order.

${ }^{13}$ Stephen Gosson, Playes Confuted in Fiue Actions (1582), in Markets of Bawdrie: The Dramatic Criticism of Stephen Gosson, ed. Arthur Kinney (Salzburg, 1974), p. 175.

${ }^{14}$ William Harrison, The Description of England (1577), ed. Georges Edelen (Ithaca, N.Y., 1968), p. 147.

${ }_{15}$ Thomas Beard, The Theatre of Gods Ivdgements, Short-Title Catalogue (STC) 1661 (London, 1631), pp. 419-20. Earlier editions appeared in 1597 and 1612. p. 97.

${ }^{16}$ John Rainolds, The Overthrow of Stage-Playes, STC 20616 (Middleburgh, 1599),

${ }^{17}$ Adam Hill, The Crie of England, STC 13465 (London, 1595), p. 17. 
"Though this be a kind of attire appropriate only to man, yet they blush not to wear it, and if they could as well change their sex and put on the kind of man, as they can wear apparel assigned only to man, I think they would as verily become men indeed, as now they degenerate from godly sober woman, in wearing this wanton, lewd kind of attire, proper only to men." ${ }^{18}$ Female apparel-switching, in Stubbes's view, violated fundamental boundaries and distinctions; male transvestism diminished masculine character and imprinted inferior values, and both brought down clouds of divine retribution.

Stubbes, of course, overreacted, and it is easy to follow his lead. But a generation later it appeared that certain types of cross-dressing had got out of control. King James himself was so disturbed by female accessorizing with masculine attire that in 1620 he ordered the clergy "to inveigh vehemently and bitterly in their sermons against the insolency of our women, and their wearing of broad-brimmed hats, pointed doublets, their hair cut short or shorn, and some of them stilettos or poniards, and such other trinkets of like moment." And shortly after, John Chamberlain reported from London, "our pulpits ring continually of the insolency and impudence of women ... the king threatens to fall upon their husbands, parents or friends that have or should have power over them, and make them pay for it." 19 Whether this was in response to a resurgent female transvestite movement or a short-lived fashion craze inspired by revivals of The Roaring Girl is not yet clear, but whatever its origins, the kingly intervention precipitated a flurry of misogynist pamphlets, Hic Mulier, Haec-Vir, and Muld Sacke. ${ }^{20}$

The author of Hic Mulier suggested that female transvestism was rampant, "for since the days of Adam women were never so masculine." Vain and foolish women, the author charged, "have cast off the ornaments of your sexes, to put on the garments of shame." They cropped their hair, sported broad-brimmed hats, donned doublets, pulled on boots, and equipped themselves with swords. Habitués of theaters and brothels were particularly guilty of this mannish self-fashioning but, Hic Mulier

${ }^{18}$ Phillip Stubbes, The Anatomie of Abuses, STC 23376 (London, 1583), sigs. E7vF5v. For more in this vein, see Jonas Barish, The Antitheatrical Prejudice (Berkeley and Los Angles, 1981), pp. 80-92.

${ }^{19}$ N. E. McClure, ed., The Letters of John Chamberlain (Philadelphia, 1939), 2:28687, 289. This includes the King James quote.

${ }^{20}$ Hic Mulier: or, The Man-Woman: Being a Medicine to cure the Coltish Disease of the Staggers in the Masculine-Feminines of our Times, STC 13378 (London, 1620); Haec-Vir: Or, The Womanish-Man, STC 12599 (London, 1620); Muld Sacke: Or The Apologie of Hic Mulier, STC 21538 (London, 1620). The three are reproduced in Barbara J. Baines, ed., Three Pamphlets on the Jacobean Antifeminist Controversy (New York, 1978). 
alleged, "It is an infection that emulates the plague, and throws itself amongst women of all degrees, all deserts, and all ages, from the Capitol to the cottage." Like Stubbes's Anatomie of Abuses, Hic Mulier saw experimental fashion as a violation of divine as well as social order. Gender-specific costume- "a coat for the man and a coat for the woman" - was modeled by the "great work-master of heaven." Dressing in the wrong coat called in question the entire design of the cosmos. ${ }^{21}$

By the time of Charles I the transvestite controversy appears to have died down-at least the pamphlet polemic was muted-but it was revived in 1633 by a new spate of puritan attacks on the stage. William Prynne's contentious Histrio-Mastix refocused attention on costume and gender, authenticity and representation. Prynne poured scorn on men who would "adulterate, emasculate, metamorphose, and debase their noble sex" by acting womanish parts or putting on female costume. Like Gosson and Stubbes before him, Prynne cited Deut. 22:5 to prove that "God himself doth expressly inhibit men to put on woman's apparel, because it is an abomination to him." Even someone "who puts on a woman's raiment but to act a part, though it be but once, is doubtless a putter on of woman's apparel ... and so a grand delinquent against God." The effect of such abominable behavior-inevitably in Prynne's view-was to shame nature by making men monstrous and effeminate and to unleash the sins of lustfulness, sodomy and self-pollution. ${ }^{22}$ The Caroline preacher Daniel Rogers concurred that "effeminate disguisings and arrayings of one sex in the other's attire" were among the "extravagances of senses and sensuality" to be abhorred at all times. ${ }^{23}$

\section{II}

Against this fundamentalist critique, which forms a buttress of the literary scholarship on transvestism, I would like to introduce some fresh archival material that introduces that rarest of rare birds, an actual (or nonfictional) cross-dresser, caught in the act, in early Stuart England. Since it comes from the archives it belongs to a genre traditionally labeled as "evidence"' but, given our awareness of the fictionality of court

${ }^{21}$ Hic Mulier: or, The Man-Woman, sigs A3, A4, Bv-B2, C, B2v-B3. See also John Taylor's attack on "shameless double-sexed hermaphrodites, Virago roaring-girls, that to their middle, to know what sex they were was half a riddle," quoted in Bernard Capp, The World of John Taylor the Water Poet, 1578-1653 (Oxford, 1994), 115.

${ }_{22}^{2}$ William Prynne, Histrio-Mastix: The Players Scovrge, or Actors Tragadie (London, 1633), pp. 171-72, 179-80, 182-83, 206-9.

${ }^{23}$ Daniel Rogers, Matrimoniall Honour: Or, the Mutual Crowne and Comfort of Godly, Loyal, and Chaste Marriage (London, 1642), p. 174. 
reporting, it may be better to call it a "story." ${ }^{24}$ Shaped by the requirements of the law and the practices of the clerks, the church court records preserve many people's stories where recollection and obfuscation blend to create a partial narrative. Like most such stories, the one that follows serves for more than entertainment or delight since it opens a window onto complex cultures of the past. What makes a story significant, rather than merely interesting, is the landscape it illuminates, the contours it reveals, and the opportunity it presents to examine opaque attitudes, conduct and speech.

The following story involves gender and generational relations, limits and breaches of customary activity, normal and abnormal ceremonies of childbirth, and one of the few documented cases of nontheatrical maleto-female cross-dressing in early modern England. It illuminates social and legal responses to deviant behavior and, if pushed hard enough, may be made to expose cultural tensions and social accommodations in the reign of Charles I. To understand it we need to consider the customs and culture of childbirth, puritan polemic about transvestism, comedy on the early Stuart stage, and the practice of the ecclesiastical courts. Following the threads of this story-unraveling the tangle-involves confrontation with a variety of issues and engagement with the interests of several academic disciplines.

Our window opens at Tew Magna, Oxfordshire, in 1633, the same year as Prynne's diatribe against cross-dressing in Histrio-Mastix. Tew Magna-Great Tew-is best known in the reign of Charles I as the literary retreat of Lucius Cary, Lord Falkland, who was lord of the manor in the 1630s. In an important essay on this community Hugh TrevorRoper (Lord Dacre) remarks that "we have all heard of the Great Tew Circle," an observation that sadly now has diminishing force. Falkland's "'Great Tew Circle,' which included philosophers, churchmen, and poets, is renowned for its high-minded reflection and learned conversation, "convivium philosophicum, or convivium theologicum." 25 Humbler inhabitants of Great Tew make no appearance in Lord Dacre's version of cultural history; so it is both startling and rewarding to encounter Great Tew villagers in a tale of transgression that cuts to the heart of gendered identity and social practice in early modern England.

On December 7, 1633, Francis Fletcher, midwife, the wife of Ed-

${ }^{24}$ Natalie Zemon Davis, Fiction in the Archives: Pardon Tales and Their Tellers in 16th Century France (Stanford, Calif., 1987); David Cressy, "De la fiction dans les archives? Ou le monstre de 1569," Annales: Économies, sociétés, civilisations 48 (1993): 1309-29.

${ }^{25}$ For the "Great Tew Circle" see Hugh Trevor-Roper, Catholics, Anglicans and Puritans: Seventeenth Century Essays (Chicago, 1988), pp. 166-230, quote on p. 166. 
ward Fletcher of Tew Magna, Oxfordshire, appeared before the archdeacon's court to answer some serious charges. As a midwife her behavior fell within ecclesiastical cognizance, and she most likely had a licence awarded by the church. Francis Fletcher admitted that

she doth practice midwifery ... at such times as her neighbors do require. Being further demanded whether she did help Hugh Rymel's wife of Tew to be delivered, she saith she did; and being further interrogated whether Thomas Salmon her servant did come to the labor of the said Rymel's wife, or presently after she the said Rymel's wife was delivered, disguised in woman's apparel, she confesseth he did come into her chamber some six hours after she had been delivered so disguised, but by virtue of her oath she sayeth at his first coming she knew him not, but afterwards, she discovering by her daughter-in-law her clothes which the said Thomas Salmon had on, she made him to depart the room, and was no way privy to his coming or to his disguise. ${ }^{26}$

The incident was outrageous on several counts. It was inherently disorderly, even if it did not lead to a ruckus. It was an affront to the traditions of childbirth, discourtesy to the mother and her friends, demeaning to her husband and family, and discredit to the profession of midwifery. Whether it was also a threat to the stability and sanctity of gender identity, an abomination unto the lord, and a symptom of sexual disorder, will be among the concerns of this discussion.

Women normally gave birth in the company of other women and celebrated their safe delivery in a conclave of sisterly visiting. The childbed room was a place of "mysteries," a privileged female domain from which even the father of the child was excluded. Men had no place there, and remained ignorant of how women conducted themselves behind the veil. Recent work on the cultural history of childbirth has emphasized the degree to which it was a gender-segregated event. ${ }^{27}$ The birthroom belonged entirely to women, except in dire medical necessity. Any male presence was transgression.

How could the midwife Fletcher have allowed Thomas Salmon's unprecedented invasion? To what degree was she responsible for this rupture of the traditional ceremony of childbirth? As keeper of the cere-

${ }^{26}$ Oxfordshire Archives, Oxford, Oxford Archdeaconry Office Acts, c. 12, fol. 75 . Subsequent citations of this case are on fols. $75 \mathrm{v}, 81,151$.

${ }^{27}$ Adrian Wilson, "The Ceremony of Childbirth and its Interpretation," in Women as Mothers in Pre-industrial England, ed. Valerie Fildes (London, 1990), pp. 68-107; Audrey Eccles, Obstetrics and Gynaecology in Tudor and Stuart England (Kent, Ohio, 1982). Robert Herrick refers to "the child-bed mysteries" in his poem, "Julia's Churching, or Purification," in Hesperides (London, 1648). 
monies, was she answerable for losing control of the customary process? Was she in any way liable at law? Had she failed to uphold the standards of her profession and the provisions of her midwife's oath, which, among other items, required her to "be secret, and not open any matter appertaining to your office in the presence of any man, unless necessity or great urgent cause do constrain you' ${ }^{28}$ Worse, was she complicit in this compound violation of gendered costume and female space, in which her own servant and daughter-in-law were principals? By permitting her cross-dressed manservant to sit with the newly delivered mother and her gossips, the midwife Fletcher was accessory to grave misbehavior, for Thomas Salmon's offence lay in his presence as well as his genderbending disguise.

With understandable delicacy, the court sought to resolve several problems. How did a man come to intrude into the female domain of the birth room, and what was the meaning or significance of his crossdressing? How did the intruder conduct himself, and why was he not immediately recognized? Why did his face, voice, or manner not discover him, and his subterfuge only collapse when his mistress belatedly attributed ownership to his clothing? What were his feelings and intentions, who were his accomplices, and what did it all betoken? What can such an unusual incident tell us about the culture of the 1630s?

The next witness before the court was Elizabeth Fletcher, the wife of John Fletcher of Tew Magna and daughter-in-law to the midwife. In the course of describing the conventional social courtesy whereby neighboring women crowded the chamber of a newly delivered mother-in itself rare documentation of a delicate and opaque topic-she explained how that practice was violated. Being asked,

whether she did help Thomas Salmon, her father-in-law's servant, to put on woman's apparel and go to goodwife Rymel's house, she being then in labor or newly delivered, she sayeth that she herself being at her labor about two of the clock in the afternoon, seeing her well laid in her bed, came home to her own house and stayed there till nine of the clock the same night, and at nine of the clock she this examinate saying that she must go to Rymel's house to be merry with the other women there, Thomas Salmon her father's servant then replied that there would be good cheer, desired that he* might go along with her.

${ }^{28}$ Doreen Evenden, "Mothers and Their Midwives in Seventeenth-Century London," in The Art of Midwifery: Early Modern Midwives in Europe, ed. Hilary Marland (London and New York, 1993), pp. 9-26. For the midwife's oath, see The Book of Oaths (1649; reprint, London, 1689). Ben Jonson plays on women's secrets and mysteries in Epicoene, or The Silent Woman, STC 14763 (London, 1620), 4:2, 5:3. 
(*At this point the court scribe, anticipating the climax of the story, and evidently confused by shifting gender, wrote "she" instead of "he" and then crossed out the letter "s." This scribal slippage underscores the instability of gender categories.)

Elizabeth's testimony continued: "and afterward, at the request of the said Thomas, she helped to dress him in woman's apparel and consented to let him go to the said Rymel's house, intending only merriment thereby." Whether she meant merriment for herself, or amusement for Thomas Salmon, or laughs all round, is not immediately clear. But it is evident that Elizabeth Fletcher was of a younger generation, perhaps no older than the servant; she had scant respect for her mother-in-law's position or the dignity of midwifery, and she certainly did not behave with the gravity expected of a respectable married woman. At best, by her own account, the younger woman helped to perpetrate an outrageous practical joke; at worst, by the standards of contemporary reformers, she had colluded in a most sinful abomination unto the lord.

The final statment came from Thomas Salmon himself. The court described him as "nuper de Tew, nunc de South Newton," so apparently he moved to another village after the scandal (or perhaps after his servant's contract expired; we have the date of the court hearing, but not the date of the birth-room incident. Nor, unfortunately, do we know Thomas Salmon's age, which may be a critical factor in the story.). When asked "who was privy to the dressing of him in woman's apparel," he answered

that at the said time he hearing that there would be good cheer at the house of Eleanor Rymel who was then lately brought a-bed, wished that he might be there; whereupon his dame Elizabeth Fletcher said he should, and then fetched her apparel, and he put off his doublet and he came to the said house where the women met, and bid them say that he was Mrs. Garrett's maid, and that his mistress sent him to see how she did, which he did; and he stayed there in the room but a little, but he continued in that apparel about two hours.

If Thomas Salmon can be believed, no offense was intended. But people under investigation by the ecclesiastical courts commonly sought to minimize the gravity of their offence and to mitigate its circumstances. (For example, people presented for refusing to kneel at the altar sometimes claimed arthritis, and those presented for keeping their hats on in church said they had cold heads.) Salmon admitted that he had insinuated himself into the most private and secret of female gatherings but claimed innocence of evil or deviant intentions. No man had been present at the 
vital moment of parturition, or had sight of the mother's privities, so the gynecological mysteries of the birth room were preserved. The young servant understood that there would be good cheer at the postdelivery lying-in, and that, as usual, the drinking, eating, and gossiping would be enjoyed exclusively by women. He simply wanted some of that good cheer. His cross-dressing, from this perspective, was a response to scarcity, a means to temporary betterment, comparable to that of certain disadvantaged women who are known to have passed themselves as men. ${ }^{29}$ Egged on by Elizabeth Fletcher, Thomas Salmon impersonated a neighboring maidservant and was permitted by the assembled women to take his seat among the gossips. His ruse was helped by the customarily low light level in the dimly lit birth room, after nine o'clock at night. If the gossips had been drinking, as by custom they would, the intruder's disguise might be still more secure, especially if Elizabeth Fletcher was prepared to support his pretense. Only the midwife's recognition of her daughter-in-law's clothes on a visitor purporting to be someone else's maidservant aroused suspicion and led to the intruder's dismissal. This may sound disingenuous (both his account and mine), but there is not enough evidence to judge whether Salmon was devious or deviant, a simpleminded innocent or a pervert seething with complex desires.

Having heard from the midwife, the court let her go without punishment. She, as much as the other women of Tew, was a victim in this affair. Her daughter-in-law, Elizabeth Fletcher, was ordered "to make acknowledgement of this her fault in such manner as shall be delivered her." And the court accepted Thomas Salmon's confession and assigned him a formal penance. The incident was closed with punishments that were remarkably mild. The court had done its duty in disciplining youthful folly but found nothing gravely amiss by the laws of church or state.

Is this a case, like the Sherlock Holmes mystery, of a dog that did not bark? Should we expect to find a greater sense of outrage in the ecclesiastical records? Should we assume, following recent critical suggestions, that Thomas Salmon was effeminized by his wearing of women's clothing, that his male identity was compromised and an alternative self revealed? Should we be sensitized to the unleashing of erotic energies, attuned to the notion of pollution, and alert to cries for retribution in the outraged community of Great Tew? Was Salmon himself, or anyone else, sexually aroused by this activity? What did the other Great Tew circles think - the women, the men, the clergy, the gentry-when Thomas Salmon's transvestite behavior was exposed? Even if we cannot

${ }^{29}$ Rudolf M. Dekker and Lotte C. van de Pol, The Tradition of Female Transvestism in Early Modern Europe (New York, 1989), p. 2. 
find the answer, it is well worth asking how the young man felt while his mistress's daughter-in-law dressed him in women's clothes? And why did he continue to wear the borrowed garments for two hours after his sex had been discovered? Did he delight in his unaccustomed costume, was he parading or bragging or carousing at the alehouse, or was he simply unable to undo the points without assistance and could not get the borrowed clothing off? There is nothing in the record that explicitly relates Thomas Salmon's offense to the virulent prohibition on apparelswitching set forth in Deuteronomy and nothing that makes overt connection to the complaints about cross-dressing that had reverberated for more than fifty years. Yet, if recent literary scholarship is to be believed, crossdressing was high on the cultural agenda of early modern England, gender identity was subject to intense and troubled scrutiny, and reformers were quick to denounce violations of gendered apparel. The case of the Great Tew cross-dresser provides a point of leverage for examining several of these suggestions.

Thomas Salmon's violation of clothing conventions and customary behavior-his transgression of gendered dress, gendered space and gendered social acitivity - followed a period that some scholars have labeled "the transvestite controversy." 30 From the 1570 s to the 1620 s, during the reigns of a manly queen and a queenish king, England is said to have been challenged by disorderly people presenting themselves in public in a gender-confusing manner. Late Elizabethan and Jacobean England emerges, especially in some gay and feminist literary history, as a golden age of cross-dressing. Whether the available evidence bears some of the interpretations that have been strung on it remains a matter for critical discussion.

In reconsidering this topic, we need to differentiate kinds of behavior that the moralists deliberately blurred. We need to distinguish occasional deployment of items of cross-gender costume from full genderbending transvestism, while recognizing, with the moralists, that divine wrath knew no such discrimination. We need to understand when apparel was designed, like a provocative accessory, to heighten the wearer's sexual identity (as with The Roaring Girl) and when, by way of disguise, to hide it (like Thomas Salmon). We need to know what messages were sent by dress, what signals received, and how costume could be used to entice, to shock, to entertain, to convince, or to confuse. What, for example, was the cultural charge of a codpiece or doublet, a petticoat or bodice, points and ruffs, and how did their resonance change when items were appropriated by the opposite sex? Robert Herrick, Prynne's contem-

${ }^{30}$ Woodbridge (n. 3 above), p. 139. 
porary (and Thomas Salmon's), wrote that "A sweet disorder in the dress / Kindles in clothes a wantonness," and went on to fetishize his lady's petticoat, stomacher, and shoe strings. In another poem Herrick is almost overcome by the "liquefaction" and "brave vibration" of "Julia's clothes," as if the texture and swish of the garments was directly erotic, not just because Julia was wearing them. ${ }^{31}$

\section{III}

It is still something of a novelty for social historians to engage with creative literature, particularly in light of Peter Laslett's strictures on looking "the wrong way through the telescope." ${ }^{32}$ But the printed output of English Renaissance drama provides a huge trove of text, almost entirely neglected by historians, that calls for cautious investigation. Representations of male cross-dressing on the early Stuart stage may supply a distant analog for Thomas Salmon's behavior at Great Tew, as well as a model for responses to his offence.

Whereas female dramatic characters who dress as men are usually presented as admirable, resourceful, and effective-one thinks of Shakespeare's Rosalind or Viola-it is commonly argued that men who dress as women are more often rendered as comic or ridiculous, their circumstances degraded and their manhood diminished by a feminizing costume. ${ }^{33}$ Similarly in Renaissance romance, it is suggested, cross-dressed heroes fall victim to ridicule and degradation. Rosicleer in The Mirrour of Knighthood (1580) dresses as a noble wife in order to deceive a tyrant. Don Belianis in The Honour of Chivalrie (1598) disguises himself as a woman in order to effect his escape. Sir Arlanges and Prince Agesilan in Amadis de Gaule (1577) impersonate young ladies in order to pursue a loved one at court. Pyrocles in Philip Sidney's Arcadia disguises himself as an Amazon for similar reasons. But their female costume unmans them, and in their cross-dressed state they begin to adopt womanish traits and both men and women fall in love with them. ${ }^{34}$ On stage too, the

${ }^{31}$ Robert Herrick (1591-1674) was a Devonshire minister in the 1630s. "Delight in Disorder" ("A sweet disorder in the dress ... ") and "Upon Julia's Clothes" ("When as in silks my Julia goes ...') come from Hesperides, as does "Julia's Petticoat."

${ }^{32}$ Peter Laslett, "The Wrong Way through the Telescope: A Note on Literary Evidence in Sociology and Historical Sociology," British Journal of Sociology 27 (1976): 319-42.

${ }^{33}$ See works by Levine (nn. 3, 8 above); and Woodbridge. Compare the treatment of men in women's clothing in William Shakespeare, The Merry Wives of Windsor (performed 1597); and Thomas Heywood, The Brazen Age, STC 13310 (London, 1613).

${ }^{34}$ Louise Schleiner, "Ladies and Gentlemen in Two Genres of Elizabethan Fiction," Studies in English Literature, 1500-1900, 29 (1989): 1-20; Winfried Schleiner (n. 8 above), pp. 605-19; Constance Jordan, Renaissance Feminism: Literary Texts and Political Models (Ithaca, N.Y., and London, 1990), pp. 223-28. Pyrocles in James Shirley's 
temporary transvestism marks humiliation, as in the case of Falstaff who is dressed as the old woman of Brentford in The Merry Wives of Windsor.

But this is not always the case. Rather than being effeminized, the cross-dressed man is more often rendered as proactive, virile, and effective. His dissimulation is a means to advancement, not downfall. In Jacobean comedy (though not in dramatic criticism) the transvestite male appears more energized than emasculated by his temporary change of clothes. (So, mutatis mutandi, is Mary Frith's remarkable womanhood both problematized and intensified by her cross-dressing as The Roaring Girl.) More than two dozen plays from the Elizabethan and Jacobean stage feature a man disguised as a woman who becomes the perpetrator rather than victim of practical jokes, outwits an opponent through ludicrous mistaken wooing, or achieves sexual success through the comic infiltration of female society. Most commonly the cross-dressing is played for laughs, without suggestion of a gender system in trouble.

Thomas in John Fletcher's Monsieur Thomas impersonates his sister. Welford in Francis Beaumont and John Fletcher's Scornful Lady impersonates his friend's fiancée. Iustiniano in Dekker and Webster's Westward Hoe adopts his wife's attire. Wily dresses as a seamstress's maid in The Comedy of George a Green. Walgrave becomes Susan in Haughton's Englishmen for my Money. Bold is disguised as a waiting woman in Nathan Field's Amends for Ladies. Follywit takes the guise of a courtesan in Middleton's A Mad World, My Masters. And in Ben Jonson's Epicoene, or the Silent Woman, the subject of considerable recent attention, the central character is a male disguised as a woman who mingles freely with the ladies. ${ }^{35}$ Even if male to female cross dressing was rare in the streets and villages, it was a common device on the London stage.

In one of the earliest plays, George a Green, also known as The Pinner of Wakefield, George's servant Wily enters Grime's house "dis-

\footnotetext{
stage version of The Arcadia (1640) "played the man indeed," though dressed in "feminine shape"; see William Gifford and Alexander Dyce, eds., The Dramatic Works and Poems of James Shirley (London, 1833; reprint, New York, 1966), 4:175-218.

${ }^{35}$ John Fletcher, Monsieur Thomas, STC 11071 (London, 1639), performed ca. 1610-13; Francis Beaumont and John Fletcher, The Scornful Ladie, STC 1686 (London, 1616; reprint, 1625, 1630, 1633, 1639); Thomas Dekker and John Webster, West-ward Hoe, STC 6540 (London, 1607); A Pleasant Conceyted History of George a Greene, the Pinner of Wakefield, STC 12212 (London, 1599); William Haughton, English-men for my Money; or . . a Woman Will Have her Will, STC 12931 (London, 1616; reprint, 1626, 1631); Nathan Field, Amends for Ladies, STC 10851 (1618; reprint, London, 1639); Thomas Middleton, A Mad World, My Masters, STC 17888 (London, 1608); Ben Jonson, Epicoene (first performed by the Revels children in 1609). Among these, only Epicoene has featured extensively in recent critical scholarship. See, e.g., Rose (n. 3 above), pp. 50-64; and sources cited in n. 6 above. See also Victor Oscar Freeburg, Disguise Plots in Elizabethan Drama (New York, 1915), pp. 102-8, 117-19, 190-91.
} 
guised like a woman," a seamstress's maid, to help Grime's daughter Bettris run away to her lover. The ruse works so well (despite Wily's face being covered as if "troubled with the tooth-ache sore") that Grime calls him/her "a pretty wench of smiling countenance" and works up a proposal of marriage. The cross-dressing achieves its comic end, deceiving Bettris's father, and is approvingly described as "this subtle shift" when Wily reveals himself to be a boy.

Follywit's impersonation of a courtesan in A Mad World, My Masters, is applauded as one of his admirable "mad tricks." "'Tis an Amazonian time," he remarks, combining his own masculine doublet with part of a gentlewoman's costume (act 3, scene 3; hereafter denoted 3:3). Cross-dressed to gull his grandfather, he also allows himself to be courted and kissed by his grandfather's steward (4:3). The satire is cruel and amusing, skewering both gullible men and predatory women, but Follywit himself is unaffected by his temporary change of attire.

In Ben Jonson's Epicoene neither audience nor most of the characters know until the very end that the Silent Woman is, like Wily, a boy in disguise. Mistaken wooing is the central joke of the play. Unlike the other male cross-dressers in Jacobean drama, Epicoene has no prior independent role as a male until he is revealed as an instrument of Dauphine's plotting. As a woman, he/she appears "exceeding fair, and of . . sweet composition ... loving and obedient" and, at first, silent, satisfying all of Morose's requirements in a wife (2:5). In his feminine role, Epicoene is adopted by the ladies collegiate to learn their "secrets," including "those excellent receipts, madame, to keep yourselves from bearing of children" (4:2), and is apparently initiated, more than Thomas Salmon ever was, into the subculture of female fertility. Ultimately, of course, Dauphine reveals Epicoene's true gender-“a boy, a gentleman's son, that I have brought up this half year, at my great charges" (5:4) - a relationship that may hint at bisexuality and homoeroticism. But gendered cultural boundaries are preserved by Epicoene's promise not to reveal "any mysteries" he has learned of the women. Like George a Green's "subtle shift," Dauphine's ruses in Epicoene are applauded for their "bravery and a wit" (2:4) and for "sport" that is "full and twanging" (5:3). True-Wit, who takes the role of a choral commentator, leads the audience in applause for "concealing this part of the plot," a forerunner of the "surprise" in the film The Crying Game (1993). ${ }^{36}$

Cross-dressing is also a matter of "sport" in John Fletcher's Monsieur Thomas (first performed about 1610). This play features an onstage

\footnotetext{
${ }^{36}$ Jonathan Crewe, "In the Field of Dreams: Transvestism in Twelfth Night and The Crying Game," Representations 50 (1995): 101-21.
} 
robing scene in which Thomas, like Thomas Salmon, is dressed by his female accomplice. Dorothy and her maid paint Thomas's face and help him dress in woman's clothing, in a knockabout scene with jokes about breeches, points, and buttocks. Coached in female graces and taught to curtsey like a woman, Thomas asserts his manhood by filling the room with a monstrous (and masculine?) fart (5:1). But attired as a woman, Thomas is confident in his female disguise: "Everyone takes me for my sister, excellent" (5:2). But the disguise is far from perfect. The audience knows about it from the beginning, Thomas's femininity is grotesque, and other characters quickly see through his imposture. "I saw his legs, h'as boots on like a player, under his wenches clothes; 'tis he, 'tis Thomas in his own sister's clothes," cries the servant Launcelot, betraying Thomas to his father $(5: 1)$.

The disguise, however, is good enough to trick Valentine, the father of Thomas's beloved Mary, and Hylas, a lecherous old gentleman, who is persuaded that the "lady" is in love with him. (Hylas describes his bride-to-be as "fair gentlewoman" and "the sweetest woman, the rarest woman, and the lustiest but wondrous honest," and before being cruelly humiliated excuses Thomas's rough cheeks and lips when he kisses him/ her [5:6, 5:9].) Thomas's woman's clothes admit him to Mary's bedroom, and indeed to her bed, but the women of the house, who know perfectly well who he is, play a trick on him (5:5). More successfully, his crossdressed disguise also allows Thomas to enter a nunnery where he "plays revel rout," as one nun tells the abbess, like "the fiend . . . among us." He certainly makes no attempt to hide his sex, once he has gained entry to this female sanctum, although, like Thomas Salmon at Great Tew, he remains in female costume. Cellide, a novice, asks him, "what are ye ... and . . . what would ye with me?" Thomas: "Any thing you'll let me." Cellide: "You are no woman, certain." Thomas: "Nor you no nun, nor shall be" (5:10).

What is evident from all this is that Thomas, despite his woman's apparel, is not the least unmanned. Indeed, his lustiness is enhanced, his libido uplifted, by the tricks he describes as "sport." He ridicules others, and is himself made ridiculous, in the interest of the trickeries of the plot. If there is a sexual charge to Monsieur Thomas's cross-dressing, it is in the access it gives him to female bodies, not in any erotic frisson from the women's clothes themselves. The play may help answer Peter Stallybrass's question, derived from Rainolds, whether woman's clothes on a man awaken desire for a woman or to be a woman. ${ }^{37}$

${ }^{37}$ Peter Stallybrass, "Transvestism and the 'body beneath': Speculating on the Boy Actor," in Zimmerman, ed. (n. 3 above), p. 76. 
By the same token, Walgrave in Englishmen for my Money, salaciously subtitled A Woman Will have her Will, is not the slightest bit effeminized by dressing in woman's apparel. Rather, his dressing as Susan wins him Mathea, his heart's desire, and his masculine potency is vigorously aroused and satisfied by the effectiveness of his disguise. Still wearing woman's clothing, after a night in bed with Mathea, Walgrave seeks blessing from her father, Pisaro, "for I have blessed you with a goodly son; 'tis breeding here, i' faith, a jolly boy." Walgrave's disguise as the neighbor's daughter Susan had so convinced Pisaro that the old man courted her and called her/him "sweeting," a joke that everyone but Pisaro could share (scenes 11 and 12). Walgrave's cross-dressing, like Monsieur Thomas's and Wily's, is a sport, a jest, a trick, a stratagem, which earns him his reward, congratulation from most of the other characters, and the humiliation not of himself but of others thought deserving to be humbled.

Nor is Welford unmanned when he dresses in woman's clothes and pretends to be espoused to Loveless in Beaumont and Fletcher's The Scornful Lady. Welford's cross-dressing, like most in this comedic genre, is another stratagem, "a slippery trick," designed to "overreach" and "be even" with the Scornful Lady herself (5:1). Dressed in woman's clothes, Welford makes a virtue of his unwomanlike "ugliness" by claiming to "use no paint, nor any drugs of art," and appears as "a good plain wench" in need of comfort after being jilted by a lover. Martha, the Scornful Lady's sister, takes pity on this seemingly distressed gentlewoman and charitably invites her indoors: " 'Tis very late, and you shall stay all night. Your bed shall be no worse than mine; I wish I could but do you right" (5:2). And you can imagine the rest. Next morning Welford reports, "what a pretty fury she was in, when she perceived I was a man; but I thank God I satisfied her scruple, without the parson of the town," and Martha and Welford are forthwith married. The Scornful Lady, herself now won by Loveless, admits to being completely taken in by Welford's disguise: "What a dull ass was I, I could not see a wencher from a wench; twenty to one, if I had been but tender like my sister, he had served me such a slippery trick too." And addressing Welford she continues, "my large gentlewoman, my Mary Ambree, had I but seen into you, you should have had another bedfellow, fitter a great deal for your itch" (5:4). Mary Ambree, frequently mentioned in these plays, was an Elizabethan woman who passed as a soldier and was thus an archetype of gender disguise. The "itch," too, was replete with sexual meanings.

Nathan Field's comedy Amends for Ladies is even more a riot of cross-dressing and complex gender reference. In the course of this drama, 
Frank, "attired like a woman," pretends to be married to his brother Ingen, who is trying to win the love of Lady Honour and even allows Ingen to kiss him/her $(2: 3,3: 2)$. Lady Honour herself later takes the disguise of a footboy and is wounded by her unknowing brother, Lord Proudly (4:3). Lord Feesimple dresses "like a lady, masked," and is farcically courted and kissed by his own father, the count who responds, "'Sfoot! She has a beard! My son?" (5:2). The play even features a topical appearance by Moll Cutpurse, the roaring girl, a woman dressed up as a man and addressed as "Mary Ambree" and "Mistress hic and haec," referring to the Hic Mulier controversy (2:1). But the central action of the play concerns Bold, a gentleman suitor who spends most of the drama in woman's costume.

Bold first appears "disguised as a waiting gentlewoman," and it is not clear how the audience would know that he was a man cross-dressed as a woman, rather than a conventional male actor playing a female part. Perhaps there was some stage business to tip the wink, like Monsieur Thomas with his farcical curtsies. Lady Bright, however, the object of his attentions, takes Bold at her/his word as a waiting gentlewoman named Mary Princox (another name with sexual connotations) and accepts her/him into her service. Princox claims to be escaping Bold's attempt at seduction, allowing the suitor, though dressed as a woman, to assert his lusty manhood while reportedly attempting to seduce himself. Bold's disguise is so good that Lord Feesimple, convinced of her "truth and honesty," himself pays court to her: "an't please God, that thou wert not past children"' (1:1).

Ensconced in Lady Bright's service, Bold as Mary performs the duties of a waiting gentlewoman, pinning and unpinning her mistress, all the while chatting of feminine topics. The scene is heavy with satire, irony, risque jokes and double entendre, with considerable discussion of clothes. Eventually Lady Bright concludes, "well, well, come to bed, and we'll talk further of all these matters," to which Bold says, aside, "Fortune, thank thee ... now she is mine indeed" (3:3). Given Thomas's attempt on Mary, Welford's bed trick with Martha, and Walgrave's overnight success with Mathea, one might expect to find Bold having his way. But Lady Bright is not so easily taken on finding her female bedfellow to be a man. The lady defends her honor, threatens to cry rape, wields a sword (itself a masculine accoutrement), and bids the intruder begone. Bold's stratagem is comically undone and his sexual ambition "foiled and disgraced" $(4: 1,4: 2)$ before, in their final reconciliation, Bold and Lady Bright agree to be married.

Once again, the device of cross-dressing wins the audience's applause. The male character's "putting on of woman's apparel" is a mat- 
ter of mirth, his artificial femininity a source of "good cheer." Welford, Walgrave, and Bold are not made womanish by putting on woman's costume. Nor do they appear to be eroticized by the clothing itself. But wearing it gains them admission to intimate feminine circles, and the sexual opportunity it gives them makes them decidedly aroused. These, after all, are plays about courtship, about winning wives and property, and the overall dramatic framework within which they work is resolutely heterosexual, even if that cannot be said of all members of the acting company.

Theatrical cross-dressing is not portrayed as threatening, effeminizing, and certainly not an abomination unto the lord. But how should it be otherwise, since plays were not the voices but the targets of reformist propaganda? Theater treated costume playfully without the moral and religious weight of Histrio-Mastix, The Anatomy of Abuses, or Deuteronomy. Transvestite plotting toys with the conventions of gender distinction but does not profoundly interrogate them. Yet even in comedy the cross-dressed male may be a source of unease, and his behavior leads to dramatic complications. Though not himself humiliated or ridiculed, the butt of his deception is cruelly abused. And that may be the core of Thomas Salmon's offense, too, not the risk of emasculation he took on himself but the potential harm he did to others.

The prevalence of the disguise motif in early modern literature, with its jokes about sex and costume, suggests that the inner and outer signs of gender identity formed a topic of continuing concern, at least among playwrights and playgoers. It may even reflect anxiety. When the comedy invites us to laugh, is it the laughter of idle amusement, the laughter of venom, of disquiet, or uncomfortable self-recognition? One does not have to endorse the extreme view, that the crisis in the sex-gender system of early modern England was part of "the historical process eventuating in the English Revolution"' to agree that the putting on of female apparel could be both mildly amusing and profoundly problematic.

\section{IV}

Moving from the stage to the street, from literature to social behavior, what were the circumstances in which men and women could be clothed in the costume of the opposite sex? Is any kind of answer possible to Jean Howard's question, "How many people crossdressed in Renaissance England?" And did they compromise their gender or risk the sanctions of Deuteronomy by such actions?

Men sometimes burlesqued in female clothing during carnivals and 
pageants. "Both men and women change their weeds, the men in maids array, and wanton wenches dressed like men do travel by the way," reported Barnaby Googe in $\mathbf{1 5 7 0}$ with reference to the Shrovetide revels. ${ }^{38}$ Men cross-dressed as "May Marions" in the course of Maytide games, thereby earning the wrath of the Elizabethan critic Christopher Fetherstone. ${ }^{39}$ The charivari or skimmington used cross-dressing to ridicule and to discipline disorderly neighbors. ${ }^{40}$ Men dressed as women sometimes during enclosure riots or other public disorders, linking social protest to traditions of festive inversion, to taunt the authorities or to evade identification. ${ }^{41}$ They might occasionally don an item of female dress, or have one put on them, while carousing or drunk, like Falstaff in The Merry Wives of Windsor. Prisoners sometimes dressed as women in order to escape. ${ }^{42}$ Some men may have disguised themselves as women in order to infiltrate a forbidden place or to make a rendezvous with a lover. Some men may have worn women's clothes for the sake of erotic stimulation. Male actors, mostly boys, played women's parts on stage. Evidence can be found to document some of these situations, and imagination can supply the rest.

Women, in certain limited social settings, adopted items of masculine attire to shock, to allure, and to stretch the limits of permissible fashion. Prostitutes sometimes wore mannish gear to attract and arouse their customers. Women, too, may have dressed as men, or put on mannish costume, for pleasure, fun, or idle amusement. With more serious purpose they occasionally disguised themselves as men in order to travel, to serve in the army or navy, to meet or accompany a lover, or to avoid sexual attentions. Dutch sources from the seventeenth and eighteenth centuries record over one hundred cases of cross-dressed women in mili-

\footnotetext{
${ }^{38}$ Robert Charles Hope, ed., The Popish Kingdom or Reigne of Antichrist written in Latin Verse by Thomas Naogeorgus and Englyshed by Barnabe Googe (London, 1880), p. 48.

${ }^{39}$ Christopher Fetherstone, A Dialogue Agaynst Light, Lewde, and Lacivious Dauncing, STC 10835 (London, 1582), sig. D7.

${ }^{40}$ Buchanan Sharp, In Contempt of All Authority: Rural Artisans and Riot in the West of England, 1586-1660 (Berkeley and Los Angeles, 1980), p. 104. See also Martin Ingram, "Ridings, Rough Music and Mocking Rhymes in Early Modern England," in Popular Culture in Seventeenth-Century England, ed. Barry Reay (London, 1985), pp. 166-97.

${ }^{41}$ Natalie Zemon Davis, Society and Culture in Early Modern France (Stanford, Calif., 1975), pp. 147-49, cites English examples.

${ }^{42}$ Stephano Janiculo, an associate of Arabella Stuart, escaped a Turkish prison disguised as a woman. Prince James, later James II, is said to have disguised himself as a woman while fleeing after the battle of Worcester. Female costume was almost de rigueur for escaping from the Tower of London.
} 
tary service, at least a few of whom had taken female lovers or wives, and there are a few similar stories from early modern England. ${ }^{43}$ Women passed as men in order to better their circumstances, to obtain the privileges or work of the opposite sex. There may have been an erotic charge for some transvestite women, just as there was for some men, but more commonly their transvestism was limited, temporary, and pragmatic, addressing the needs of a particular situation. Though often associated with anxiety and disorder, not all cross-dressing was erotic or pathological or reflected a cultural system in distress.

Actual instances of women wearing male costume or men crossdressed as women rarely appear in the English historical records. (Like flag-burning or communist infiltration, it may have been more feared than practiced.) The London Bridewell and Aldermen's courts in the Elizabethan period made occasional references to prostitutes who "went in men's apparel" who apparently used their costume to advertise their trade. Dorothy Clayton, for example, was a prostitute in 1575 who "contrary to all honesty and womanhood commonly goes about the City appareled in men's attire." She was ordered to stand in the pillory for two hours "in men's attire," for public shame, and then committed to Bridewell. Another Elizabethan woman, Joanna Goodman, was punished in 1569 for dressing as a male servant to accompany her husband to war. These two incidents, grouped in Jean Howard's discussion as examples of "actual" lower-class cross-dressing, in fact represent very different engagements with masculine clothing; the prostitute cross-dressed to entice her clientele, indeed to accentuate her available femininity; the soldier's wife wore male costume in an unsuccessful operational disguise; the first was a sexual provocation, the second a practical device or ruse. ${ }^{44}$

A cluster of incidents from the ecclesiastical courts of Elizabethan Essex involved women who dressed like men. Susan Bastwick of Stondon in 1578, "whilst she was in service with her father about Allhallowtide last in a merriment came on horseback in a cloak disguised and demanded of him if he had any good ale." The court ordered her to

${ }^{43}$ Dekker and van de Pol (n. 29 above), pp. 1-14; Joad Raymond, ed., Making the News: An Anthology of the Newsbooks of Revolutionary England, 1641-1660 (New York, 1993), pp. 148, 167. The diarist Walter Younge reported ca. 1627, "there was a woman apprehended at Plymouth in the attire or habit of a man by the mayor, at the time the Earl of Denbigh and Sir Henry Martyn were to go to sea. It is said that she is one Smith's wife of London, kept by Sir Henry Martyn"; see British Library, Additional Ms 35,331, fol. 16. See also the case of Joanna Goodman in 1569, cited in text below, and references to Mary Ambree, ca. 1584, cited in text above.

${ }^{44}$ Howard, "Crossdressing, the Theatre, and Gender Struggle" (n. 1 above), pp. 420-21; R. Mark Benbow and Alasdair D. K. Hawkyard, "Legal Records of CrossDressing," in Shapiro, ed. (n. 3 above), pp. 225-34. 
seek her father's forgiveness before she next received communion. At Littlebury in 1585 a female servant "did wear man's apparel disorderly in her master's house." The churchwardens of Great Chesterford reported in the same year "that Hunt's wife, contrary to God's law, did put on man's apparel and went forth from one house to another so ungodly and shamefully, with other naughtiness of words." In 1592 the court heard that James Cornwall's wife of Terling, cited for sexual incontinence with John Burles, "useth to wear young men's garters and said she would so to do until they came for them." In 1596 the three daughters of Thomas Day of Great Wendon were cited "for going disguised a mumming," presumably in cross-dressed attire, and their father was cited "for suffering them to go." Also in 1596, in the season of Maytide merriments, Joanna Towler of Downham was "detected, for that she came into our church in man's apparel upon the sabbath day in the service time." 45

In 1612 another Essex woman, Catherine Bank, servant to John Whitebread of Grays Thurrock, was similarly presented, "for coming in man's apparel into the church . . . to the contempt of religion, thereby dishonoring God and disturbing the minister and congregation.' I would guess that like Joanna Towler she was wearing a festival costume rather than participating in any Jacobean "female transvestite movement." The court ordered her to perform penance "in her usual apparel with a paper on her breast" proclaiming her fault. ${ }^{46}$

These were mostly minor offenses, more jests and pranks than challenges to the gendered social order, and their punishment was appropriately mild. Cross-dressing here involved mockery and high spirits and provocative disrespect for patriarchy and propriety, but it is hard to see it as subversive or seriously transgressive. In most cases it was associated with seasonal merriments of Halloween and Maytide and mumming from house to house, and it only attracted notice if it crossed the line from sanctioned to irresponsible behavior, like Joanna Towler wearing her May games outfit to church. If fathers, masters, neighbors, churchwardens, or ministers were offended when young women flaunted mannish costume, and normal patriarchal discipline proved insufficient, they had some redress in the eccelesiastical courts. But the courts, more interested in restoring charity and harmony than in meting out punishment, were content to secure acknowledgment of error and to pass out a mild rebuke.

${ }^{45}$ F. G. Emmison, Elizabethan Life: Morals and the Church Courts (Chelmsford, 1973), p. 18; William H. Hale, A Series of Precedents and Proceedings in Criminal Causes (London, 1847), p. 212.

${ }^{46}$ Hale, p. 212. 
The stiffest punishment, like that enjoined on Thomas Salmon, was performance of public penance.

This, too was the official response to Mary Frith, the original Moll Cutpurse and model for The Roaring Girl, who was cited by the London Consistory Court in 1612 for disorderly reveling in masculine attire. An almost legendary historical character, Moll Cutpurse enjoyed celebrity status on the fringes of the London stage and became a character in several plays. It is significant that her cross-dressing was closely associated with the festive traditions of the theater and that her costume was designed to flaunt, not to efface her gender. Mary Frith had attended the Fortune theater "in man's apparel, and in her boots, and with a sword by her side." But any who doubted that she was indeed a woman she invited to her lodging to put the matter to the test. She was also found in St. Paul's church on Christmas night "with her petticoat tucked up about her, in the fashion of a man, with a man's cloak on her . . to the disgrace of all womanhood." Before the court Mary admitted her roistering but denied more serious charges of lewdness and bawdry. Predictably she attracted considerable attention when she performed her penance at Paul's Cross, and, in keeping with her character, despite promising to behave "honestly, soberly and womanly," she made a travesty of the punishment by turning up drunk. ${ }^{47}$

A smaller range of cases involved men who were cited for wearing women's garb. In practice the church was less concerned that they had violated the sanctions of Deuteronomy than that their behavior provoked disorder. Young men, like young women, took part in seasonal revels, May and summer games, mummings, burlesques, charivari, skimmingtons, and the village morality drama of skits and libels. Often these activities involved cross-dressing and were lubricated with good cheer, and sometimes they got out of control. If there was any sexual frisson in this festive cross-dressing, it remained well hidden. The evidence points not to homoerotic ambivalence and subversive androgyny but to problems of social discipline.

At Cawthorne, Yorkshire, in the summer of 1596, in contemptuous disregard of an order "that no rushbearings, summer games, morris dances, plays, interludes, disguisings, shows or abuses should be used . . . in any church or churchyard or upon the Sabbath day," an unruly

${ }^{47}$ P. A. Mulholland, "The Date of The Roaring Girl," Review of English Studies, n.s., 28 (1977): 17-31; Paul A. Mulholland, ed., The Roaring Girl (Manchester, 1987), pp. 262-63. The case can be found in Greater London Record Office, DLC/310, fols. 19-20. 
company assembled nonetheless in the church "and there did arm and disguise themselves, some of them putting on women's apparel, and othersome of them putting on long hair and visards", and then paraded through the town drawing the people after them. ${ }^{48}$ At Oxford in 1598, "the inhabitants assembled on the two Sundays before Ascension Day, and on that day, with drum and shot and other weapons, and men attired in women's apparel, brought into the town a woman bedecked with garlands and flowers, named by them the queen of May. They also had morris dances and other disordered and unseemly sports." 49

The following year John Wilkins of Whitstable, Kent, was cited "for going about the street in woman's apparel, being the parish clerk at that time." In his defense he explained that "at a marriage in a merriment he did disguise himself in his wife's apparel to make some mirth to the company," and this excuse appeared to satisfy the archdeaconry court. ${ }^{50}$ And finally in 1633, the same year as Thomas Salmon's outrage in Oxfordshire, Christopher Willan of Burton in Kendall, Cumberland, was cited "for bearing rushes to the church or chapel disguised in women's apparel." This took place in the course of a traditional rush bearing (the ceremonial garlanding of the church), and it is likely that the reformers were more offended by Willan's perpetuation of a superstitious ceremony and its affront to ecclesiastical good manners than by his costume. ${ }^{51}$

The church was concerned with order and discipline, the sanctity of the holy space and the dignity of the sabbath.$^{52}$ Ecclesiastical regulators were preoccupied with propriety and decorum, and one of their recurrent concerns was to maintain limits. It may have been permissible to cross-dress on the green, but offensive if the celebrants came unchanged to church. Wedding guests might play with gender and clothing by way of "merriment," but questions of propriety were raised when one of the merry-makers was the parish clerk. Mary Frith could get away with cross-dressing at the Fortune theater, but masquerading in St. Paul's no. 7.

${ }^{48}$ Borthwick Institute, York, Court of High Commission, Cause Papers, HCCP 1596,

${ }^{49}$ H.M.C., Calendar of Cecil MSS. at Hatfield House (1899), 8:201.

${ }^{50}$ Arthur Husey, ed., "Visitations of the Archdeacon of Canterbury," Archaeologia Cantiana 27 (1904); 226.

${ }^{51}$ Borthwick Institute, York, Metropolitical Visitation of the Diocese of Chester, V. 1633, Court Papers, fol. 113v.

${ }^{52}$ Peter Lake, "The Laudian Style: Order, Uniformity and the Pursuit of the Beauty of Holiness in the 1630s," in The Early Stuart Church, 1603-1642, ed. Kenneth Fincham (London, 1993), pp. 161-85, draws attention to the Laudian view of the church as the "house of God." 
church brought down the wrath of the bishop of London. The primary offense that needed remedy lay, not in the gender confusion or abomination of cross-dressing, but in the intrusion of inappropriate behavior into privileged space. This is why the East Anglian women and the north country men were cited for coming cross-dressed to church, and it helps us to understand the issues surrounding Thomas Salmon's invasion of the birth room at Great Tew. What the village community found truly offensive was not that the manservant dressed as a woman but that he used this disguise to enter a place where he did not belong. If dirt, as Mary Douglas has observed, ${ }^{53}$ is a substance out of place, then Thomas Salmon may have been doing something dirty, and his presence in the birth room a pollution. At issue was where he was, not what he wore. The critical matter in this case, then, may have been genre rather than gender, and the latter a subset of the former.

What is striking about the Great Tew case is that neither the church court nor the Oxfordshire community appeared to share the anxiety or outrage about cross-dressing exhibited by the London antitheatrical critics. Prynne's vituperative strictures, though exactly contemporary with Thomas Salmon's dressing-up, seem to have occupied a different world. Nor does the report of the offense or the testimony of the witnesses suggest that gender disorder was anywhere near as serious as some recent literary historians have assumed. Neither Thomas Salmon's behavior, nor Elizabeth Fletcher's, fits the model of subversion, oppression, or opposition advanced by radical critics. Nor does it have much to offer champions of sexual liberation, resistance, and "transgressive reinscription." Instead, we see a reasonableness and sense of accommodation that accorded with the style and philosophy of the better-known intellectual circle at Great Tew.

Of course, there were strains in early modern society, and questions about gender roles and identity, but it is hard to argue that they were more acute than at other times. Nor can it be claimed with confidence that gender mattered more than other social, economic, religious and political problems. The evidence suggests that cross-dressing in practice was neither the subversive abomination nor the eroticized transgression that some scholars have claimed. Neither the records of ecclesiastical justice nor the London comedies reveal, in my reading, a sex-gender system in crisis. Indeed, one could argue that the system was robust enough to play with, with a measure of festive tolerance and allowance for good clean fun.

Other scholars may read the sources differently and make more of

${ }^{53}$ Mary Douglas, Purity and Danger (London, 1969), esp. pp. 4, 113. 
the case of Thomas Salmon, but it would be misleading to claim him as grist for any particular mill. The danger, in these matters, lies in projecting present preoccupations onto the past and in bringing our opinions to the evidence rather than deriving them from it. There may well be politicized erotic energies at work here, but not all of them belong to the sixteenth and seventeenth centuries. 